\title{
Associated States and British Dependent Territories
}

\section{Antigua}

The tourist potential of Antigua lies in its pleasant climate, its unique scenery and excellent beaches. It is a tropical island near to the great concentration of population in the north eastern United States and Eastern Canada. It is accessible and can offer many of the unspoilt natural facilities required by the tourist.

1.

Value and Extent of the Tourist Industry

$\begin{array}{ll}\text { Number of tourist arrivals, } & 1967: 59,174 \text { (excl. cruise ship } \\ & 1968: 55,838(" \text { passengers) } \\ 1969: & 61,262(") \\ & 1970: 65,369(")\end{array}$

Visitors come mainly from the U.S.A., Canada and the U.K. About $97 \%$ arrived by sea in either passenger or cruise ships. In 1970, approximately 70 cruise ships made calls to Antigua.

Total receipts from tourism, 1966: $\$ 17,156,000 \mathrm{EC}$ 1967: \$18, $132,000 \mathrm{EC}$ 1968-1970: not available

The Tourist Industry has been the main growth sector in recent years, and has generated a very rapid growth in distribution services and constmuction. The average length of stay is 4.7 days.

Coolidge Airport is the only airport in the Lesser Antilles which is equipped to accommodate transatlantic jet aircraft. There are direct services to Europe, Canada and the United States, and daily scheduled flights to all tha other islands in the Caribbean. Coolidge is served by Air Canada, Air France A.L.M., B.O.A.C., B.W.I.A., Caribair, LIAT, Pan American and Sea Green Air Charter Services.

2. Official Promotion Organisation

The Antigua Tourist Board operates on a budget of $\$ 75,000$. It was set up by Government under the supervision of the Ministry of Trade, Production and Tourism to help promote and develop the tourist industry in Antigua. In this connection the members of the Board have endeavoured to advertise the industry in the United Kingdom, Europe, the United States and Canada. These activities are carried out with the support of the Hotel Association and the airlines serving the region. The Antigua Tourist Board has a paid Secretary and staff, and operates an office in St. John's, as well as the Tourist Information Booth at Coolidge Airport. The Tourist Board is a member of the Association of Tourist Boards of the Eastern Caribbean, and also the Caribbean Travel Association. 
3. Internal and Infrastructural Organisation

(a) The Hotel Association and Employers Federation

(b) Travel Agents

(c) Airlines

(d) The Antigua Taxi Association

The Tourist Board usually supplies the airlines and travel agents with information and statistics in respect of the industry.

The majority of visitors stay in hotels and guest houses where there are 946 rooms with 1,889 beds (June, 1968).

4. Government Participation

(i) Ownership in hotels:

The proposed Hotel Dulcina in Barbuda.

(ii) Financial assistance specifically available (e.g. loans and guarantees):

None.

(iii) Income tax and other concessions on hotel and other tourist income:

Hotel owners obtain income tax free holidays for five years, and thereafter in each of any five years of the next eight years of operations, the hotel owner will be allowed to set off against the income arriving from the hotel, one fifth of his capital outlay.

(iv) Import duty concessions on material and equipment for hotel and other tourist construction:

Any person who proposes to construct or equip a new hotel or extension to an existing hotel, intended to contain when completed no less than 10 bedrooms, may be granted a licence to import or purchase in the colony certain building materials and articles of hotel equipment free from customs duty and purchase tax.

(v) Provision of public funds for publicity purposes:-

Government provides the funds used by the

Tourist Board. The budget for 1968 was $\$ 75,000$. This amount included cost of operating the Tourist Information Office in St. John's, and the Tourist Information Booth at Coolidge Airport, postage, promotional material and literature, membership dues to the Caribbean Travel Association, fees for the U.K. and Canadian Representatives and a small advertising budget. Promotional activities include regional and individual island trips to the U.S.A., Canada and U.K., transport and entertainment for travel agents and travel writers 
on familiarisation tours of Antigua.

(vi) Government expenditures on infrastmucture:

Government assists indirectly by providing airfields, roads, dams for storage of water, and other services essential to the tourist industry. A deep water harbour was recently constructed, which will assist considerably in the development of the cruise ship business. A programme of major rehabilitation for Coolidge Airport has been completed, and was designed to strengthen the main runway, extend the parking aprons, and to improve lighting, aprons, taxi ways, approach and navigational aids. An extension to the Terminal Building has been constmucted. It includes eight shops and a departure lounge. A new fire station has also been provided under the Rehabilitation Scheme.

5. Future Plans for the Industry

The Antigua Government will continue to give high priority to the continued development of this industry; however, more consideration will be given to the idea of treating the industry as a regional industry with regional promotion and development programmes. As regards promotion, greater effort will be put into the development of the summer traffic, with a view to achieving not only a higher occupancy rate, for this period, but also for the year as a whole. 


\section{Bahamas}

The tourist potential of the Bahamas lies in its excellent climate with a variation of temperatures of only $10^{\circ}$ to $12^{\circ} \mathrm{C}$ throughout the year. Also, in its beaches, 700 islands, incredibly clear waters as well as many sporting activities such as deep sea fishing, sailing, golf, scuba diving and casinos. Superior hotels and a variety of types of holidays may be obtained depending on which island you choose to vacation on. There are also superb group and convention facilities.

1. Value and Extent of the Tourist Industry

The Bahamas have shown a phenomenal growth in tourism since the statistics were first recorded. This was in 1949 when the visitor count was 32,000. Since then the Bahamas have shown a steady increase and in 1968 the notable 1,000,000 visitor mark was reached. In 1970 the fast-paced growth slowed down and a small decline of 2.6 per cent was recorded.

\begin{tabular}{lcc} 
Year & Number of Visitors & \% \\
\cline { 2 - 3 } 1966: & 822,317 & +14.1 \\
1967: & 915,273 & +11.3 \\
$1968:$ & $1,072,213$ & +17.1 \\
1969: & $1,332,396$ & +24.27 \\
$1970:$ & $1,298,344$ & -2.6
\end{tabular}

Visitors came mainly from the U.S.A., Canada and Europe. In 1970, the breakdown was as follows:
U.S. visitors
Canadian visitors
European visitors
(including U.K.)
$87.39 \%$
$4.25 \%$
$3.34 \%$

The average length of stay for air visitors was 5.3 days. The 1970 visitor figure included $381, \overline{8} 65$ cruise ship passengers.

Tourist expenditure in the calendar year 1969 was estimated at 235 million U.S. dollars. The estimate is based on a sample survey. Estimates of tourist expenditure for 1970 are now being completed and are expected to be lower than in previous years. A study made by a group of consultants in 1969 showed that tourism accounts for 71 per cent of the Gross National Product and provides from direct and indirect sources, nearly 60 per cent of the total revenue.

\section{Official Promotional Organisation}

The Ministry of Tourism headed by a Minister and administered by a Director of Tourism is responsible for the development and promotion of tourism in the Bahamas. There is a statutory Tourist Board but with advisory 
functions. The Board advises the Ministry on problems which impinge on tourist promotion and on local matters such as transport, hotels, shopping, educational facilities and usually holds eight meetings a year. There is also a Facilitation Committee which deals with immigration and customs controls, entry and departure procedures and facilities at port of entry. The Ministry maintains ten offices overseas, eight in the U.S.A., and one in Canada (Toronto) and one in Europe, based in London. There are also field representatives in Atlanta, Montreal and Frankfurt, Germany. All the offices in the U.S.A. and Canada are directly administered by a General Manager, stationed in Miami. The Ministry maintains in Nassau a News Bureau which provides information, photographs and editorial matter to foreign and local press and to travel magazines and writers in particular. The News Bureau also provides necessary assistance to visiting travel writers, photographers and members of the foreign press and T.V. and radio stations. The Ministry of Tourism, which is a member of the International Union of Official Travel Organisations and its Regional Travel Commission for the Americas, and its representatives have been quite active in the deliberations, of these two bodies. The Director of Tourism and senior officials of the Ministry and its overseas offices are also allied members of the American Society of Travel Agents.

Internal and Infrastructural Organisation

The majority of tourists who came by air stay in hotels or guest

houses. There are over 10,000 hotel rooms available in the Bahamas, as follows:

New Providence and Paradise Island Freeport and Grand Bahama Island

4. Government Participation

(i) Ownership or shares in hotels:

None.

(ii) Financial assistance specifically available (e.g. loans and guarantees):

None.

(iii) Income tax and other concessions on hotel income:

There is no income tax in the Bahamas.

(iv) Import duty concessions on material and equipment for hotels or other tourist construction:

A Hotels Encouragement Act enables refund of entire duty importation on materials, fixtures and furniture to encourage the growth of new hotels. No refund is granted on imports of foods, beverages, and consumable articles.

(v) Provision of public funds for publicity purposes:

The Ministry of Tourism is voted an annual budget for the administration and promotion of tourism in the 
Bahamas. In 1970 the budget amounted to $\$ 6,780,413$

Bahamian dollars. This is broken down for

administration, promotion, public relations and

advertising.

(vi) Government expenditure on infrastructure:

The Bahamas Government has spent about twenty million dollars on dredging and construction of a new pier in Nassau harbour and close to four million dollars on extending the runway to 11,000 feet at Nassau International Airport and on enlarging the terminal building. The largest liners can now dock right at the pier and the largest aircraft can land as well as take off with full payload. The Ministry of Tourism spent about five hundred thousand dollars in developing a sound-and-light show at Fort Charlotte in Nassau. Considering the rapid increase in the number of visitors in a group of islands of which the total population is less than 180,000 , the Government has had to spend considerable amounts of money on expanding other facilities required by tourists such as roads, electric supply, telephone services etc. However, the private sector has in many cases provided their own public utilities in resorts. The Ministry of Tourism have provided incentives to rather picturesque horse driven carriages called surreys and to native night clubs so that these institutions which are found highly attractive by visitors are able to maintain good standards.

5 . Action Taken During the Current Year

Apart from the normal advertising and public relations activities undertaken on behalf of the Ministry of Tourism by advertising and public relations agents, the $\mathrm{M}$ inistry in conjunction with the Hotel Association participated in off-shore promotions to Canada, United Kingdom, Sweden, Germany, Switzerland, Mexico and various parts of the U.S.A. Over 800 United States and Canadian travel agents were entertained in the Bahamas and escorted on familiarisation visits. Hotels individually also hosted large groups of travel agents throughout the year. The Ministry of Tourism's offices abroad continually solicit and aid the travel trade as well as incentive houses and special group-oriented organisations. The Ministry of Tourism sponsored a Professional Golfers Association International Tournament, the'Bahamas Islands Open", in Freeport, Grand Bahama Island in December. The event will be an annual tournament known as the "Bahamas National Open".

6.

Future Plans for the Tourist Industry

The Government has set up a Projects Co-ordinating Committee consisting of representatives of several Ministries. Proposals for construction of new hotels and other related facilities such as marinas, golf courses etc., are scrutinized by the Co-ordinating Committee and recommended to the Government for approval. There is continued expansion of hotel and supplementary accommodation as also other tourist facilities. On the whole, about 1,000 new hotel rooms are expected to be added in the foreseeable future. 


\section{Bermuda}

The tourist potential of Bermuda lies in its excellent climate, its great scenic beauty, the hospitality and friendliness of the Bermudians and the close proximity to the eastern seaboard of the United States of America.

A wide choice of attractions, sporting activities and entertainment for visitors augurs well for the continuing prosperity.

1. Value and Extent of the Tourist Industry

$\begin{array}{lll}\text { Number of tourist arrivals }, & 1967: & 281,167 \\ & 1968: & 331,379 \\ 1969: & 370,920 \\ 1970: & 388,914\end{array}$

The majority of the visitors, $87.23 \%$ came from the U.S.A., $8.49 \%$ from Canada and $0.63 \%$ from the United Kingdom.

Foreign exchange receipts from tourism,

$$
\begin{array}{ll}
1967: & \$ 51,949,000 \\
1968: & \$ 62,683,000 \\
1969: & \$ 65,000,000 \text { (estimate) } \\
1970: & \$ 72,800,000
\end{array}
$$

Access facilities by air and sea are excellent.

2. Official Promotional Organisation

The Government's Department of Tourism and Trade Development is the responsibility of the Executive Council Member for Tourism and Trade Development Affairs. The Department has a Director and supporting staff in Hamilton and branch offices in New York, Chicago, Toronto and London. It works in close liaison with the private sector of the industry in Bermuda.

The official publicity branch of the Department is the Bermuda News Bureau. It supplies news and feature stories to the overseas media. Its writers, photographers and production staff in Bermuda also cover special events for news distribution through its overseas branches.

3. Internal and Infrastructural Organisation

In 1969 there was a total of 6,245 beds and in 1970 a total of 7,000 beds available to visitors in recognised hotels, guest houses and cottage colonies. The average length of stay in 1969 was 5.9 nights and in 19706.0 nights.

Training - The Bermuda Hotel and Catering College is an 
institution of further education under the jurisdiction of the Department of Education. The college is fully equipped and staffed to provide training in every facet of the hotel operation leading to professional qualifications recognised and accepted everywhere.

Travel Agencies - In each of the last three years about a thousand agencies have visited Bermuda from the U.S.A., Canada and the U.K. plus a few from Europe.

4 .

Government Participation

(i) Ownership or shares in hotels:

None.

(ii) Financial assistance specifically available (e.g. loans and guarantees):

None.

(iii) Income tax and other concessions on hotel income:

There is no income tax in Bermuda.

(iv) Import duty concessions on material and equipment for hotel and other tourist construction:

None.

(v) Provision of public funds for publicity purposes:

The majority of the budget of the Department of Tourism is expended on publicity and promotion of the Island. The budget in 1969 was $£ 1,271,000$ and in 1970 was $\$ 3,173,228$.

(vi) Government expenditure on infrastructure:

None.

5. Action Taken During the Current Year

The Hotels (Licensing and Control) Act 1969 was put into effect during the year resulting in a large number of smaller guest houses being licensed and included in the literature available about Bermuda.

Close liaison between the Department of Tourism and the hotels and carriers resulted in a co-ordinated programme of advertising in American and Canadian newspapers and a booklet to promote the off-season, "Rendezvous Time".

6. Future Plans for the Tourist Industry

To prevent overcrowding of the amenities and facilities of the Island, it was realised that a policy to reduce the number of cruise vessels and therefore the number of passengers to be catered for at any one time would have to be implemented. The Hotel phasing and policy adopted three years ago was finalised and aims to limit the growth of hotel accommodation to a rate when it can be more easily staffed by Bermudians. The schedule will be kept under annual review. 


\section{British Honduras}

The tourist potential of British Honduras is centred around its temperate climate, Mayan archaeology and the excellent opportunities for sport fishing, and aquatic sports. Hunting, bird-watching and sightseeing also command a great deal of interest. The friendly cosmopolitan population presents an appealing diversity of culture, traditions and occupational preference.

1. Value and Extent of the Tourist Industry

Approximately 31,588 visitors (including business and official visitors) came to Belize in 1970 . These were mainly from Mexico, the U.S.A., Canada and Central America. The great majority of these came by road.

Official Promotional Organisation

The Tourist Board, broadly representative of the interests directly involved in the industry, has day-to-day responsibility for carrying out promotion efforts authorised by the Ministry. Its Secretary liaises with the Ministry, conducts studies, correspondence, etc. and assists visiting travel writers and investors.

The Minister has final responsibility for all policy matters relating to tourism development, including development concessions.

Although the Board has no formal affiliation with any external organisation in the field of promotion, representation has been arranged at travel shows in the U.S.A. and there is an informal arrangement under which the West India Committee, London, acts in certain matters on behalf of the Government of British Honduras.

\section{Internal and Infrastructural Organisation}

With the development of tourism plant on the offshore islands and along the southern coast, tourists are tending to spend less time in Belize City where attractions and facilities are rather limited.

Countrywide, there are about 700 rooms, very few in the de-luxe or first-class range. There are three well established travel agencies with a few small ground-tour, boating and sports-fishing agencies.

Tourism development is a subject of great interest on the part of the local Chamber of Commerce. Although a formal Hotels Association does not exist, interest in constituting such a body and seeking affiliation with the Caribbean Hotels Association has been expressed by the management of the most important hotels.

The Taxi Drivers' Association is a strong and influential body. It has been instrumental in organising special capacitation courses for taxi guides. 
Training: The Tourist Board conducted an Official Guide Course for Taxi Drivers during 1970. Nine taxi drivers successfully completed the course and were awarded certificates.

The Board co-sponsored a Food Handlers Seminar which was organised and conducted by the Health Department the other sponsor.

Hotel Management was added to the list of subjects for which scholarships are granted but no award was made in 1970 .

One scholarship in Hotel Catering was awarded during the year under British Technical Assistance and an application has been made for one award in 1971.

Possibilities of obtaining training in tourism marketing and other specialised subjects will be explored, and it is hoped to organise, conduct and sponsor local training in various fields allied to tourism during 1971.

4. Government Participation:

(i) Ownership or shares in hotels:

None.

(ii) Financial assistance specifically available (e.g. loans and guarantees):

Limited tourism plant financing under the Development Finance Corporation which has government participation in its equity capital.

(iii) Income tax and other concessions on hotel income:

The Development Incentives Ordinance, 1960, provides for tax holiday periods including the production period of up to thirteen years for approved hotel construction. This is accompanied by exemption from income tax on earnings.

(iv) Import duty concessions on material and equipment for hotel and other tourist construction:

Approved projects may be exempted from import duty and income tax on capital goods.

(v) Provision of public funds for publicity purposes:

A small allocation was made for publicity and promotion activities under the tourism budget, a portion of which was expanded on the embossing of aerogrammes depicting scenes of the country.

(vi) Government expenditure on infrastructure:

All visitor facilities at the major archaeological sites and popular tourism routes were maintained and new improvements added under the local budget. 
Normal promotion and limited advertising abroad resulted in a steady and satisfactory flow of visitors. Overland visitors continued to be in a majority. Three tourism projects received development concessions during the year.

6.

\section{Future Plans for the Industry}

An application has been made under foreign technical assistance for the services of a consultancy firm to assess the country's tourism potential and the planning of its development. The terms of reference for the assignment are as follows:

(i) To make an inventory of facilities and potentials infrastructure - accommodation - services - capital.

(ii) Evolve both a short-term (say 5 years) and master sectoral plan for the next 20 years and to advise on sources of financing.

(iii) Identify and select specific projects in order of priority and to carry out the pre-investment studies as required.

(iv) Advise on zonal concept for specific development areas and projects e.g.

(a) National Parks with an emphasis on recreational aspects including coral gardens.

(b) Beaches.

(c) Archaeological centres.

(d) Areas of special cultural and historical interest.

(e) Fishing (Sports).

(v) Advise on an organisational structure and machinery to implement, monitor and promote the tourism plan.

(vi) Advise on areas in which to concentrate on the promotional effort to attract tourists.

It is hoped that this assistance will be provided in 1971 .

Funds have been approved for an extensive road improvement programme and it is hoped that with better roads the number of overland visitors will increase considerably.

English Caye a small island about 12 miles away from Belize City was declared a port of entry for the use of vessels which have obtained permission to bring passengers into the territorial waters of this country for recreational purposes only. 


\section{British Virgin Islands}

The tourist potential of this group of more than 60 islands, islets, rocks and cays lies in the numerous natural endowments which include the pleasant sub-tropical climate, many secluded white sandy beaches, considerable beauty, safe anchorages for yachtsmen, waters teeming with game fish (the B.V.I. holds no less than four international world records) and the pleasures of exploring these comparatively undeveloped islands.

Value and Extent of the Tourist Industry

The tourist industry in the British Virgin Islands, though still in its youth has shown such outstanding signs that one can safely say that it is now getting its feet off the ground. Last year's (1970) arrivals showed an increase of 12.2 per cent over the preceding year, and a projected increa se of nearly 40 per cent is estimated for the current year 1971. The figures for the previous year's arrivals were:

$$
\begin{array}{ll}
\text { 1969: } & 29,513 \\
\text { 1970: } & 33,128 \\
1971: & 46,380 \text { (projected total) }
\end{array}
$$

There has been a marked improvement in communications with the principal tourist departure points in the Western Hemisphere; and the regular flights of Prinair and LIAT to Beef Island Airport have also added to this. Communication by sea is mainly by ferry boats, operating between the British Virgin Islands and St. Thomas. The hydrofoil service has not been operating satisfactorily during 1970, but plans are being made to improve the sea communications in both the ferry and the hydrofoil systems.

In spite of the above, however, the day-tourist traffic potential from the neighbouring United States Virgin Islands is still on the upward trend.

The added advantage where connections for travellers from North America and Europe by air via San Juan, Puerto Rico, and via Antigua still remains. There is also a regular fortnightly steamer communication between the United Kingdom and the British Virgin Islands offering only limited passenger accommodation.

The British Virgin Islands, now a member of ECTA, is also being promoted by this Association through promotional tours to the United Kingdom and the Continent of Europe, Canada and the United States of America. The West India Committee still continues its British Virgin Islands representation in the United Kingdom.

2 .

\section{Official Promotional Organisation}

The Administrative Secretary for Development Planning and Tourism is responsible for the preparation and distribution of tourist information and assists Government in infrastructural development in the tourist field and the 
development of an overall plan for tourism. His responsibilities include the promotion of investment in both public and private sectors of the islands' economy.

The Statutory Tourist Board is responsible for the preparation and dissemination of tourist information. The recent publication of the newsletter, "Welcome", met with overwhelming success and has been labelled as a master job of the Tourist Board and the Hotel and Tourist Association. Hundreds of copies have been distributed in Canada, the United States, United Kingdom and other countries. The above publication was made possible through the initiative of the Administrative Secretary, Tourism.

The Caribbean Travel Association advertisement programme of the ' 8 th Continent of the World' has also been well received in various countries of the world. Official brochures are also being used in the promotion field.

The main wharf in the centre of Road Town will eventually become a landing place for tourists and the erection of a display centre will prove an asset to the tourist trade of the Territory.

There are information offices in the United Kingdom (London) and in the United States of America (New York), and soon there will be others in other countries.

3. Internal and Infrastructural Organisation

The majority of visitors stay in hotels or guest houses which are owned by private individuals. There are well over 600 hotel and guest-house beds.

The Beef Island Airport is adequate for the receipt of Avro 748 aircraft.

There are now three travel agencies in the islands, all of which are based in Road Town, Tortola, the capital and seat of Government of the Virgin Islands.

Training schemes are being pursued with colleges and schools outside the islands. Plans are being made for the training of hotel staffs and a school will be started in the near future on a regional basis through U.K. Technical Assistance.

4. Government Participation

(i) Ownership or share in hotels:

None at present.

(ii) Financial assistance specifically available (e.g. loans and guarantees):

None.

(iii) Income tax and other concessions on hotels income:

The income arising from a newly erected hotel is exempt from income tax for a period of seven or ten years or in the case of an extension for a period of ten or 20 years. 
Similarly, the Pioneer Services and Enterprises

Ordinance provides that in certain circumstances an industry may be declared "Pioneer Enterprise" providing for exemption from income tax for a period of ten years.

(iv) Import duty concessions on material and equipment for hotels or other tourist construction:

The present Hotels Aid Ordinance gives special concessions to persons who construct or extend hotels of not less than four bedrooms.

Specified building materials and equipment are allowed duty-free entry. Special duty-free concessions are granted to "Pioneer" manufacturers for the importation of equipment, plant and building materials for the establishment or extension of a "Pioneer" enterprise.

Note: The Fiscal Review Committee produced a number of recommendations for the restructuring of machinery for the collection of Government revenue.

(v) Provision of public funds for publicity purposes:

Government provides some financing for the activities of the Department of Tourism and also the Information Services.

(vi) Government expenditure on infrastructure:

Government is involved in an ambitious programme for the provision of roads, electricity, water and sewerage systems and a deep water harbour. This is progressing satisfactorily. The Water Supervisor has received further training during the year through U.K. Technical Assistance.

\section{Action Taken During the Current Year}

A portion of the runway at the Beef Island Airport was renovated in order to help secure the safety of aeroplanes when landing and taking off.

LIAT and Prinair offices have been set up to take care of up-todate bookings of passengers. There has been a big increase in the Territory's promotional efforts - the joining of ECTA membership and due to this, promotional tours undertaken to the United Kingdom, Europe, Canada, and the United States of America. The West India Chronicle continues to feature the British Virgin Islands.

The newsletter "Welcome" was published in February and met with success. Hundreds of copies have been distributed in many countries.

6.

Plans for the Future of the Industry

There has been steady improvement in communications with Canada, the United States of America, the United Kingdom and Europe and consequently 
plans are underway for the construction of new hotels in the Territory. Extension to other hotels is also being carried out.

A hotel staff training school has been discussed during the year and it is hoped that this will get underway.

A survey was carried out by Mr. J.L. Nichols, a British national, with wide experience in both hotel training and manpower projections in February. 


\section{British Solomon Islands}

The tourist potential of the Solomon Islands lies in the beautiful scenery, the friendliness of the people and an interesting variety of customs, handicrafts, songs and dances. Artificial islands, an undersea volcano, large lagoons, hot springs and a sacred mountain are all to be found here. Rare shells, abundant bird life and big game fishing opportunities offer further potential. Historical connections with the bitter campaigns of World War II provide additional interest for many visitors.

1.

Value and Extent of the Tourist Industry

$\begin{array}{rrrr}\text { Number of tourist arrivals, } 1967: & 514 \\ 1968: & 563 \\ 1969: & 1,131 \\ 1970: & 1,809\end{array}$

Visitors are mainly from Australia and United States.

During 1970 5,202 cruise ship passengers made a one day visit to Honiara.

No information is yet available on foreign exchange receipts from tourism.

2. Official Promotional Organisation

The British Solomon Islands Tourist Authority, whose members are appointed by the High Commissioner, is the organisation responsible for tourism development. Present membership consists of three representatives of the SolomonIslands people, three representatives from various sections of the industry and three civil servants.

The objectives of the Authority are set out in the 1969 Ordinance and are as follows:

(a) to foster the orderly development of tourism in the Protectorate ;

(b) to stimulate the acceptance of the tourist industry and the recognition of its value;

(c) to establish and operate or assist tourist bureaux;

(d) to promote and control the provision and improvement of facilities and attractions for tourists;

(e) to secure local and overseas publicity for tourist facilities and attractions in the Protectorate;

(f) to co-ordinate the activities of persons providing or intending to provide services for visitors to the Protectorate;

(g) to provide to visitors such protection and safeguards as to it may seem appropriate and practicable; and 
(h) to make recommendations to and advise the High Commissioner in relation to any measures which may be taken to further any of the foregoing matters.

The Authority is a member of the Pacific Area Travel Association and the Melanesian Tourist Federation.

3. Internal and Infrastructural Organisation

Hotel accommodation at the end of 1970 provided 62 rooms. There was a 12 bungalow tourist resort with licensed restaurant on Guadalcanal and cottage or rest-house accommodation at seven other localities throughout the Solomons. An internal airline provides scheduled services to eleven airfields throughout the Solomons and a further three airfields are available for charter flights. There are two tour operators now established.

Three representatives of the commercial sector are members of the B.S.I. Tourist Authority.

4. Government Participation

(i) Ownership or shares in hotels:

At present, none.

(ii) Financial assistance specifically available:

The Agricultural and Industrial Loans Board, whose interest rates are generally below the ruling commercial ones, may provide loans.

(iii) Income tax and other concessions on hotel income:

May be available, depending on individual cases. It should be noted that company tax at 25 per cent is lower in most countries and that personal income tax has a ceiling of 25 per cent.

(iv) Import duty concessions on material and equipment for hotel and other tourist construction:

Rates on most items vary between free and 17 per cent with items of Commonwealth origin receiving preferential treatment.

(v) Provision of public funds for publicity purposes:

In 1971 the Tourist Authority has received a grant of $\$ 10,000$ from Government.

(vi) Government expenditure on infrastructure:

The Government in carrying out its general development programme, has improved airport facilities, roads etc., all of which aid tourist development; it has not up to the present provided infrastructure specifically for tourism.

5. Action Taken During the Current Year

Not available at time of publication. 
6. Future Plans for the Industry

It is hoped that further hotel accommodation will be provided in Honiara in the very near future. Encouragement is also being given to possible development in the Western Solomons where considerable tourist potential exists. 


\section{Cayman Islands}

The tourist potential of the Cayman Islands lies in its delightful climate; beaches which compare with the best in the Caribbean; exceptionally clear water sports, game fishing and sailing; good inexpensive hotels and proximity to the American continent.

1. Value and Extent of the Tourist Industry

$\begin{array}{lll}\text { Number of tourist arrivals, } & 1967: & 10,278 \\ & 1968: & 14,460 \\ 1969: & 19,411 \\ 1970: & 22,888\end{array}$

Mainly from United States (approx.70\%) and Canada (17\%) (1971).

About 75 per cent spend whole holidays in the Caymans and the remainder spend at least five days combined with visits to other Caribbean holiday centres.

Ninety-nine per cent of tourists arrive by air.

Foreign exchange receipts from tourism, 1970: US $\$ 4,943,808$. earnings.

Tourism accounts for over half the territory's foreign exchange

2. Official Promotional Organisation

The Cayman Islands Tourist Board was formed on 1st January 1966 and there are tourist agencies in New York and Miami, U.S.A. Also, as a member of the Caribbean Travel Association (C.T.A.), the Cayman Islands sends its representatives to all meetings concerned with tourism in the Caribbean.

3. Internal and Infrastructural Organisation

Tourists stay in hotels, residential clubs or rented cottages. A total of approximately 900 beds are available on the islands.

4. Government Participation

(i) Ownership or shares in hotels:

None.

(ii) Financial assistance specifically available (e.g. loans and guarantees:)

None. 
(iii) Income tax and other concessions on hotel income: There is no income nor company nor profits tax.

(iv) Import duty concessions on material and equipment for hotel and other tourist construction:

Reduced duty concessions on building materials, furniture and equipment.

(v) The provision of public funds for publicity purposes: Government maintains the local Tourist Board which covers publicity.

(vi) Government expenditure on infrastructure:

The Government of the Cayman Islands finances the local Tourist Board and, within the limits of its financial resources, it does all it can to finance and to encourage the tourist industry; e.g. no income tax, no company or profits tax and reduced duty concessions on building materials, furniture and equipment for hotels.

5 .

Action Taken During the Current Year

The Tourist Board, through a combination of advertising publicity and sales promotion again effected a record year for tourism during 1970 . North American travel agents, airline personnel and travel writers were brought to this territory and a new publicity department was set up within the Tourist Board. Several apartments are under construction and some extensions are being made on existing hotels.

6.

Future Plans for the Tourist Industry

Construction of a major hotel will commence during 1971. Also needed are more restaurants, shops, a golf course and a tennis club. The Government plans to control the growth of the tourist industry and gambling in any form will not be allowed. 


\section{Dominica}

The tourist potential of the island lies in the extent and scenic value of its tropical forests which cannot be equalled in any area so accessible to visitors from Europe and North America. Complementing the forests are impressive mountains, many rivers, waterfalls, lakes and hot and cold springs. The coastal scenery has many good swimming beaches and is fringed with palms and lush tropical vegetation.

1. Value and Extent of the Tourist Industry

Dominica's tourist industry is still very young, but there is a considerable potential which remains to be tapped.

$\begin{array}{ll}\text { Number of tourist arrivals, } & 1967: 7,173 \text { (excl. cruise ship } \\ & 1968: 9,977(" \text { "passengers) } \\ & 1969: \text { " } 4,246(") \\ & 1970: \text { not available }\end{array}$

These visitors come mainly by air (approx. 85\%); the majority come from North America.

Dominica is served daily by both Leeward Islands Air Transport and Caribair from the other islands in the Caribbean, and by British West Indian Airways from New York and Miami through connections at either Antigua or Barbados; by B.O.A.C. from London, Bermuda and New York, by Air Canada from Montreal and Toronto with similar connections.

2. Official Promotional Organisation

There is a Tourist Board supported by the Government to the extent of $\$ 12,000 \mathrm{EC}$ in 1968 . Development plans envisage an office and reception building costing $\$ 40,000$ and an annual expenditure on promotion of $\$ 25,000$.

3. Internal and Infrastructural Organisation

There are about 150 hotel beds available in three small hotels catering for tourists, and some guest houses (June, 1968). There is an airport of adequate standard for the reception of Avro 748 type aircraft.

4. Government Participation

(i) Ownership or shares in hotels:

470 Government shares valued at $\$ 46,996 \mathrm{EC}$ in the Fort Young Hotel.

(ii) Financial assistance specifically available (e.g. 
loans and guarantees):

None.

(iii) Income tax and other concessions on hotel income:

The Development Incentives Ordinance provides for the granting of certain relief from income tax to companies in development enterprises which include the construction etc., of hotels and other tourist accommodation.

(iv) Import duty concessions on material and equipment for hotel or other tourist construction:

The Hotels Ordinance provides for the importation of certain building materials and articles of hotel equipment free from customs duties.

(v) Provision of public funds for publicity purposes:

See Section 2 above.

(vi) Government expenditure on infrastructure:

Government participates indirectly by the provision of roads, airports and the installation of electricity and water.

5. Action Taken During the Current Year

Not available at time of publication.

6. Future Plans for the Tourist Industry

As the tourist industry begins to assume growing significance for Dominica, the outlook will inevitably become more progressive. The Government is not unmindful of the manner in which the potential for tourism is highlighted in the Tripartite Economic Survey of the Eastern Caribbean Territories. However, any comprehensive proposal for overall development in Dominica awaits specific and detailed studies of the existing possibilities. 


\section{Gibraltar}

Gibraltar's tourist potential stems from the historic and cultural associations with Britain extending over 267 years, the benefits Gibraltar has to offer as a Mediterranean resort with sun, sea, beaches and competitive shopping and her geographic position both as gateway to North Africa and at the entrance to the Mediterranean.

In recent years there has been a strong swing in emphasis from transit tourism to development as a resort.

1. Value and Extent of the Tourist Industry

Number of visitor arrivals, $1968: 306,010$

$$
\begin{aligned}
& 1969: 220,171 \text { (including } 64,640 \text { by } \\
& 1970: 140,669 \text { ferry from Spain). }
\end{aligned}
$$

(The definition of 'tourist' recommended by the U.N. Conference on International Travel and Tourism, Rome 1963, applies to tourist statistics only subsequent to 1.1 .68$. )

The great preponderance of visitors arrive from the United Kingdom, with much smaller numbers, principally day excursionists, from Morocco, U.S.A., Germany and France.

During the period 1968-1970, there have been changes in the mode of travel of incoming visitors. The following table gives a breakdown:

\begin{tabular}{cccr} 
& $\underline{1968}$ & $\underline{1969}$ & $\underline{1970}$ \\
Arrivals $\begin{array}{c}\text { by air } \\
\text { by sea }\end{array}$ & 45,952 & 46,204 & 47,726 \\
$\begin{array}{c}\text { (by ferry from Spain) } \\
\text { by land }\end{array}$ & $\begin{array}{c}(99,135 \\
53,946)\end{array}$ & 173,967 & 92,943 \\
& $\underline{(64,640)(\mathrm{b})}$ & - \\
& $\underline{306,010}$ & $\underline{220,171}$ & $\underline{140,669}$ \\
\hline
\end{tabular}

(a) Land frontier with Spain closed to tourists 20.5.68.

(b) Ferry link with Spain ceased operations on 26.6.69.

Arrivals by sea 1968 and 1969 includes by ferry from Spain which are shown separately for statistical purposes.

The estimated net contribution of tourism to G.D.P. was $£ 0.98$ million .

2. Official Promotional Organisation

The Gibraltar Tourist Office is a department of the Government of 
Gibraltar and the Minister for Tourism and Municipal Services is responsible for policy.

The functions of the Gibraltar Tourist Office are:

(i) Promotion of Tourism - the marketing of tourism to Gibraltar including advertising, point of sale, public relations and other promotional activities such as the organisation of facility visits by members of the press, travel writers and travel agents.

(ii) Welcome Services - operation of tourist information centres at arrival points in Gibraltar and from an office in the United Kingdom.

(iii) Special Activities - management of sites of touristic and historic interest in Gibraltar;

- organisation of Festivals and other functions of cultural value to attract the tourist.

(iv) Liaison - maintainance of regular contact with all organisations connected with the tourist trade in Gibraltar and in the United Kingdom who may promote travel to Gibraltar;

- development of tourism consciousness in Gibraltar by stimulating activities designed to improve the image of the resort;

- promotion of Gibraltar to potential developers, cruise ship operators and other investors in the tourist field.

(v) Research and Development - preparation and distribution of statistical data, participation in comparative studies of tourism in different resorts;

- attendance at appropriate meetings of international and regional organisations.

3. Internal and Infrastructural Organisation

The Gibraltar Tourist Office operates from Administrative Headquarters in Gibraltar. Information offices are centrally situated in ideal premises in Main Street and at the various points of entry. To deal direct with United Kingdom enquiries - the main market for tourism to Gibraltar - a small information office is maintained in London.

The representative body responsible for putting the views of the travel and tourist industry to Government is the Gibraltar Travel Association. The Director of Tourism is an ex-officio member of the Board of this body and acts as the link through which contact with Government is maintained.

As at 31 st December 1970 , there were 12 hotels $-1,854$ beds. Seven of the establishments - 1,391 beds are of a standard acceptable to tour operators, remaining establishments being of the small private hotel type. 
Over the years there has been very little development of supplementary accommodation suitable for tourists. Conditions for the growth of boarding houses and pensions have never been appropriate. With a density of 300 persons to the acre, pressure on housing to meet the needs of the local population has always been extremely high.

The following table shows arrivals in hotels, sleeper nights, percentage occupancy and average length of stay in days for the past three years:

$\begin{array}{lccc} & 1968 & \underline{1969} & 1970 \\ \text { Arrivals in hotels } & 55,160 & 48,753 & 41,774 \\ \text { Sleeper nights } & 211,501 & 235,235 & 231,785 \\ \text { Percentage occupancy } & 57.2 & 57.6 & 48.8 \\ \text { Average length of stay (days) } & 3.8 & 4.8 & 5.5\end{array}$

Gibraltar has five beaches, all accessible to the general public. Three situated on the East side of the peninsula are sandy, while two facing West into the Bay of Gibraltar are of pebbles and stone. Over the past few years considerable improvement has been made to all beaches and to the onthe-spot amenities they provide the tourist and the resident.

Training - there is no formal training programme for personnel in the field of catering, travel or tourism. In 1971 it is intended to offer suitable sandwich courses for existing personnel. Taking into account the limited size of the labour force 700-800 in hotels, restaurants and the travel business, it is thought that better results might be obtained by flying out qualified teaching staff to conduct short courses in hotel management and kitchen and restaurant staff.

4. Government Participation

(i) Ownership or share in hotels:

Government has no ownership of hotels nor does it participate in equity of publicly or privately owned organisations.

(ii) Financial assistance specifically available (e.g. loans and guarantees):

In 1967 a hotel programme was initiated by the Government of Gibraltar. Under this programme, loan finance for approved projects was made available by H.M. Government to the Gibraltar Government for on-lending to developers at rates of interest varying in accordance with the magnitude and nature of the project. Extensions to the Rock and Caleta Palace Hotels as well as the construction of the Parcar Hotel have qualified for aid under the se arrangements.

(iii) Income tax and other concessions on hotel income:

The Development Aid Ordinance (Cap 44), provides that in the case of investments in excess of $£ 25,000$ in any one year, a developer is granted relief from 
income tax up to the amount of capital expenditure incurred on approved development projects (excluding any loan or other assistance forthcoming either from H.M.G. or the Government of Gibraltar). The Public Health Ordinance also provides for a five year period of graduated rating relief.

(iv) Import duty concessions on material and equipment for hotel and other tourist construction:

No special concessions are made on the import of material and equipment for hotels and other tourist construction. Basic building materials are however exempt from payment of duty. Current rate of duty on other imports stands at $10 \%$ ad valorem.

(v) Provision of public funds for publicity purposes:

The 1970/71 (15 months) Budget for the Gibraltar Tourist Office - $£ 155,000$ - included a sum of $£ 112,000$ available for marketing activities and the operation of an Information Centre in London. In 1971 (12 months) budget of $£ 106,000$ will include $£ 70,000$ for such activities .

(vi) Government expenditure on infrastructure:

The Government of Gibraltar has pursued a consistent policy of improvement to touristic facilities over the past years. This has been designed to strengthen the appeal of Gibraltar for the resort stay tourist and has been made possible through the provision of funds by H.M. Government. The programme has been concentrated upon improvements in the Upper Rock, to beaches, to the construction of promenades and to general beautification works .

5. Action Taken During the Current Year

Messrs. P.A. Management Consultants Ltd., a company engaged by O.D.A. at the request of the Gibraltar Government have presented a final report on "a Survey on Tourist Development to Gibraltar" and this report is currently being considered by Government.

A co-operative advertising campaign with specialist tour operators and a leading air carrier brought in significant increases in the number of enquiries.

The yearly overall figures show that air arrivals to Gibraltar from all sources increased by 3.2 per cent but against the changing pattern of cruise traffic the number of vessels calling at Gibraltar dropped from 124 to 121 in 1970 leading to a drop of 12 per cent in the number of passengers visiting the resort.

In relating the number of guest-nights spent in 1970 to that of 1969 , it should be noted that the Algeciras Ferry Service (withdrawn on 26th June 1969) accounts for 64,640 arrivals from Spain. This figure accounted for the decrease in traffic in the early months of 1970 , but despite this serious incursion into the tourist traffic, 231,785 guest-nights were sold by hotels in 1970 as compared to 235,235 in 1969 - a loss only of 4,000 guest nights. 
Guest nights sold in hotels from July to December 1970 showed a steady increase as compared to 1969 . It is pertinent to point out that for the first time a Winter Advertising Campaign was launched in 1970 and will be repeated in 1971.

In terms of hotel accommodation, there was an increase of 28.2 per cent in hotel beds as a result of extensions by the Caleta Palace Hotel, the Rock Hotel also constructed conference facilities to cater for 150/200 persons and the Both Worlds Holiday Complex on the Eastern Littoral made additional rooms available.

6. Future Plans for the Industry

It is hoped to achieve a level of 3,000 beds in 1975. The construction of a new Holiday Inns Hotel and the Parcar Hotel will bring in an additional 900 beds. The construction of a further hotel at Napier will add a further 200 to 300 beds and a further site at Parsons Lodge is also earmarked for hotel construction.

Because of the conference facilities now available, it might be possible to reduce a certain imbalance during the off-season by stimulating this type of traffic as well as the incentive holiday traffic. A conference brochure will be produced and marketing activities in provincial cities mainly designed to present the product to leading travel agents could stimulate higher levels of traffic throughout the year.

Improvement of the product is exercising the minds of the planning department and although great strides have been made in 1970 in beautifying Gibraltar, further plans for 1971 are in hand and will materialise. 


\section{Gilbert and Ellice Islands}

The potential for tourism in the islands of this Colony is considered to be both novel and adequate to warrant the creation at an early date of facilities to encourage tourism. The climate is a tropical one, but the heat is not extreme, temperatures being usually in the vicinity of 80 degrees, and the easterly trade winds preventing discomfort. Most people who choose the islands for a holiday have a certain love for the sea, and of the fun and sport which the sea has to offer. These atolls will not disappoint such visitors, offering game fishing outside the reefs, night-time reef fishing with flares, snorkling in the lagoons, sailing in outrigger canoes, motor boating and water-skiing, and swimming from the lagoon beaches. The picturesque villages and mission stations all provide interest and variety, and visitors on a flying visit to the islands cannot fail to marvel at their beauty from the air.

Value and Extent of the Tourist Industry

The value and extent of the tourist industry in these islands is negligible at present, but the administration is exploring every avenue for increasing the Colony's revenues, and at the same time is seeking some form of industry within the territory which will broaden the horizons of the islanders. The development of a small tourist industry is seen as a partial solution to this problem.

2 .

Official Promotional Organisation

None exists. Information on facilities can be supplied through the Colony's Information Services.

3. Internal and Infrastructural Organisation

There is a fully-licensed hotel ( 23 beds) at Tarawa in the Gilbert Islands, and a fully-licensed guesthouse ( 12 beds) at Funafuti in the Ellice Islands which provide full accommodation for visitors. It is likely that increased accommodation will become necessary, though no firm proposals have yet been made. There are rest houses of local design and construction on many of the outer islands in the Colony, but most of these are not provided with caretakers and offer little more than camping facilities.

Travel within the Colony may be by the internal air service which operates between Tarawa and the islands of Butaritari, Abemama and Tabiteuea, or by inter-island touring vessels on which accommodation is limited. It is sometimes possible to travel to or from Tarawa/Fiji via islands on Colony vessels, although accommodation is not of a high standard. The normal means of entry or departure is by the weekly regional air service which operates between Fiji, Funafuti and Tarawa.

The southern arm of Tarawa atoll, an urban area, is in the process of considerable development, and passenger travel is provided within the area, which covers some 25 miles of atoll rim, by taxi, motor bus and lagoon launch 
(i) Ownership or shares in hotels:

Government owns the buildings of the hotel complex at Tarawa, the operation being on lease to a local commercial organisation. Similarly, Government owns the guest house property at Funafuti; the restaurant and bar is leased to a local entrepreneur, but accommodation charges are paid to the office of the District Commissioner; Government is responsible for the maintenance of the fabric and equipment.

(ii) Financial assistance specifically available (e.g. loans and guarantees):

Limited funds are available on approved application to the Agricultural and Industrial Loans Board.

(iii) Income tax and other concessions on hotel and other tourist income:

Under an amendment to the Income Tax Ordinance, there is provision to grant certain tax concessions to companies or in respect of activities that have been declared to be pioneer companies or pioneer activities. The Protected Industries Ordinance makes provision for the protection of industries, declared as protected industries, from competition when it is in the public interest to do so and when such industries could not otherwise be developed or undertaken.

(iv) Import duty concessions on material and equipment for hotel and other tourist constructions:

Provision exists for exemptions from customs duties under certain circumstances.

(v) The provision of public funds for publicity purposes:

Limited funds are available annually within the finances of the Broadcasting and Information Department.

(vi) Government expenditure on infrastructure:

No decision has yet been taken to expand the internal air service. Improvements were made to the Tarawa aerodrome during 1970.

\section{Action Taken During the Current Year}

With major effort being directed towards other development areas in 1970, little progress was made in the development of tourism. Overseas organisations with interests in tourism and hotels in the South Pacific continued to show interest in the Colony but made no moves of any positive significance. The enactment of the Protected Industries Ordinance and an 
amendment to the Income Tax Ordinance towards the end of the year were measures designed to provide some incentive to investors.

No further progress was made towards closing the Tarawa/Majuro "air gap," but Air Nauru instituted a fortnightly Falcon jet air service between the Republic of Nauru and Tarawa, and a service exists between Nauru and Majuro.

Expansion and improvements were carried out to the Bonriki Airstrip at Tarawa during the year.

6. Future Plans for the Industry

The atolls and reef islands of the Colony are small and widely separated, forming a chain exceeding 1,000 miles in length. The distances between islands, and the distance of the two main groups from the nearest international aerodrome are a limitation to their tourist potential. The Colony cannot expect to attract tourists in any numbers until it is on a "through" air route, and in this connection the regional air carrier has had applications, for some time, before the United States Civil Aeronautics Bureau for extension of its weekly service, between Fiji and the Gilbert Islands, to the United States Trust Territories to the north, from which place tourists would have airlines connection with the Far East and the American continent. 


\section{Grenada}

The tourist industry in Grenada is in its infancy but real potential for the industry lies in the development of Carriacou in the Grenadines. With its pleasing climate, excellent beaches, attractive scenery and considerable potential for the development of yachting facilities the prospects for the tourist industry are good as soon as the airstrip at present planned, is built.

Value and Extent of the Tourist Industry

Number of tourist arrivals,

Receipts from visitors,
1968: 49,664 (incl. cruise ship

1969:

68,745 "passengers)

1970: not available

1968: $£ 3.39$ million

1969: $\$ 4.93$ million

1970: not available

Visitors come mainly by air from the United States,

Canada and the United Kingdom. The average length of stay is 10.4 days.

Grenada is served by Leeward Islands Air Transport from Peurto Rico through the Leeward and Windward Islands, Trinidad and Tobago; by Caribair from Peurto Rico; by B.W.I.A. from New York and Miami; B.O.A.C. from London, Bermuda and New York, and by Air Canada from Montreal and Toronto with connections at Barbados or Trinidad. The flying time from Barbados or Trinidad is 35 or 45 minutes by LIAT or Caribair.

Limited passenger services by sea are available from London, New York, Miami and Montreal. West Indies shipping services call at Grenada fortnightly.

2. Official Promotional Organisation

There is a small Tourist Board on the island, but this is used primarily for tourist promotion such as advertising, publicity etc.

3. Internal and Infrastructural Organisation

In 1968, there were nine resort hotels in Grenada, the largest had 60 rooms, and others ranged from 12 to 30 rooms. Most of them were ownermanaged. The average occupancy rate, estimated recently, was between $55 \%$ and $60 \%$, which is quite high by Caribbean standards.

4 .

Government Participation

(i) Ownership or shares in hotels:

None. 
(ii) Financial assistance specifically available (e.g. loans and guarantees):

None.

(iii) Income tax and other concessions on hotel income:

The Hotels Aid Ordinance encourages the hotel industry in Grenada by granting relief in respect of customs duties, income tax and real property tax to persons who expend moneys upon construction and equipment of hotels.

(iv) Import duty concessions on material and equipment for hotels or other tourist construction:

See (iii) above.

(v) Provision of public funds for publicity purposes:

The Tourist Board in the island is granted approximately $\$ 35,000$ per annum by the Government, part of which is used for promotional purposes.

(vi) Government expenditure on infrastructure:

Government participates indirectly by the provision of roads etc., and the installation of electricity and other services.

5. Action Taken During the Current Year

Not available at time of publication.

6. Future Plans for the Tourist Industry

Not available at time of publication. 


\section{Hong Kong}

Hong Kong is one of the leading tourist destinations in the Far East. Its many attractions include world class hotel rooms with unrivalled service; free port status, producing fine shopping opportunities; and the most modern amenities. Transportation and communication is readily available to every corner of the globe; and there is a temperate climate.

Value and Extent of the Tourist Industry

Number of tourist arrivals, (excluding service personnel and servicemen arriving on rest and recreation)

Foreign exchanges receipts, (excluding fares)
1967:

1968: 618,410

1969: $\quad 765,213$

1970: 927,256

1967: £ $52,377,748$

1968: £ $66,813,814$

1969: £ 87,250,034

1970: £124,536,082

As a percentage of total foreign exchange receipts, (export and re-export)

$\begin{array}{lr}1967: & 8.77 \% \\ 1968: & 9.19 \% \\ 1969: & 9.62 \% \\ 1970: & 11.89 \%\end{array}$

2. Official Promotional Organisation

Hong Kong Tourist Association - a statutory body created by Government ordinance in 1957. It is an independent organisation representative of all sections of the industry and appointed by the Government as the official tourist body.

The Hong Kong Tourist Association is responsible to $\mathrm{H}$. E. The Governor. The Association's affairs are governed by a Board of Management consisting of eleven members. Six members are selected by $H$. E. The Governor and five members are recommended to represent:

$\begin{array}{ll}\text { a. } & \text { International Carriers by Sea } \\ \text { b. } & \text { International Carriers by Air } \\ \text { c. } & \text { Hotels } \\ \text { d. } & \text { Recognised Travel Agents } \\ \text { e. } & \text { Tourist Agents }\end{array}$

The objects of the Association are:

a. To endeavour to increase the number of visitors to the Colony. 
b. To further the development of the Colony as a holiday resort.

c. To promote the improvement of facilities for visitors.

d. To secure overseas publicity for the tourist attractions of the Colony.

e. To co-ordinate the activities of persons providing services for visitors to the Colony.

f. To make recommendations to and advise the Governor in relation to any measures which may be taken to further any of the foregoing matters.

There are offices of the Hong Kong Tourist Association in the United Kingdom, Switzerland, West Germany, France, Australia, the United States of America, Canada and Japan. In addition, the Tourist Association is represented by Cathay Pacific Airways in Malaysia, Indonesia, Singapore, Thailand, South Vietnam, West Australia, Korea and the Philippines.

The Association is a member of the International Union of Official Travel Organisations, the Pacific Area Travel Association, the East Asia Travel Association and the American Society of Travel Agents and represents Hong Kong at any of the meetings of these associations.

3. Internal and Infrastructural Organisation

The headquarters of the Association is in the Central District on Hong Kong Island. Three information offices have been established to assist and advise visitors in the Colony.

The Association had a membership of 823 in 1969 and 946 in 1970. Full members who are entitled to vote at the Annual General Meeting of the Association are drawn from organisations who are active in the travel business in five categories, namely: airlines, shipping lines, hotels, travel agents and tour operators. Associate members are drawn from other organisations with interests in tourism. These members do not have the right to vote on Association affairs. The annual subscription for both types of membership is $\$ 250$ or approximately $\$ 17$. Only members of the Association are entitled to advertise in the Association's publications and to receive the benefits of the Association's decal, membership signs and recommendation by its staff.

The system of affiliated guides has been set up by the Hong Kong Tourist Association. Tour operators who are members are obliged to use only those guides who have passed exams set by the Association. In this way a high standard of guiding is ensured.

Within Hong Kong, the Association is represented on the Air Advisory Board, the Airport Facilitation Committee, the Airport Terminal Planning Board and the Trade Development Council. In addition, it is frequently called upon to take part in other ad hoc committees set up from time to time to deal with various matters impinging on the tourist industry.

The Association also assembles and disseminates detailed statistics of all visitors to Hong Kong and from time to time undertakes technical surveys to establish the position of the tourist industry in the local economy and to investigate various potential tourism development projects so that 
potential investors may have accurate technical information on such subjects.

Internal public relations is undertaken to inform citizens of Hong Kong of the importance of the tourist industry in their daily lives and to canvass support for the Association and its activities.

The number of hotels catering for tourists in 1970 was 53 with a total of 8,670 rooms. Many hotels are publicly owned although the majority are still privately owned and there is at present no star rating system. With effect from July 1966, Government has imposed a $2 \%$ accommodation tax on occupied hotel rooms.

Excluding charter flights and armed service planes, Hong Kong during 1970 was served by 21,165 flights operated by 29 international airlines on scheduled services of which Cathay Pacific Airways, a privately-owned company with its headquarters in Hong Kong, operated the most frequent service. A total of 308 passenger ships called during the same period.

4.

Government Participation

(i) Ownership or shares in hotels:

None.

(ii) Financial assistance specifically available (e.g. loans and guarantees):

None.

(iii) Income tax and other concessions on hotel income: None.

(iv) Import duty concessions on material and equipment for hotel and other tourist construction:

None.

(v) Provision of public funds for publicity purposes:

The Hong Kong Tourist Association receives an annual subvention from Government. To this figure is added a nominal revenue from member ship subscriptions amounting to $2.89 \%$ of the total subvention in $1970 / 71$. Funds provided by Government amounted to:

$$
\begin{array}{ll}
1967-8 & £ 357,143 \\
1968-9 & £ 397,959 \\
1969-70 & £ 453,608 \\
1970-71 & £ 537,671
\end{array}
$$

5. Action Taken During the Current Year

The Tourist Association's active participation in the successful promotion of Hong Kong at Expo ' 70 in Osaka was the highlight of a busy year. Due to Expo and the general increase in interest in the Far East by the travelling public, the Tourist Association played host to an exceptionally large number of travel writers, film and television units during the year, resulting in both immediate and long-range publicity of great value to Hong Kong. 
Marketing activities included detailed research on visitors' profile, habits, expenditure patterns, opinions and motivations. This study was begun in 1965. A new study was conducted and completed in 1970 on the projected need for hotel rooms in Hong Kong over the period 1971-1980.

Tourist Association films and advertisements continued their high standards, winning major awards at the 1970 conference of the Pacific Area Travel Association and the Seventh Asian Advertising Congress.

Contact was maintained with more than 500 Hong Kong students participating in the Tourist Association's successful "student ambassador" scheme, now in its third year. Lectures on tourism were also given to undergraduates at the Universities in Hong Kong.

6.

Future Plans for the Industry

a. Improvement of existing facilities;

b. Development of new classes of hotels in new locations;

c. Feasibility studies for and promotion of the development of new facilities, e.g. Oceanariums, integrated resort areas, exhibition and convention facilities, museums, craft centres;

d. Research projects to examine more thoroughly the total influence of the tourist industry on the economy of Hong Kong;

e. Market research to determine the trends in our present market and their value to Hong Kong and to evaluate possible new markets;

f. Development of more sophisticated joint marketing activities with the industry; and

g. Increased participation in the work of regional and international organisations designed to promote the world tourist industry. 


\section{Montserrat}

Montserrat possesses a sunny, invigorating and equitable climate. Its lush tropical vegetaion, its unmatchable scenic beauty, its picturesque and enchanting landscapes, its peace and tranquility and the charm and friendliness of its hospitable people make it an ideal tourist resort. Among other attractions are boiling springs at the Soufriere, relics and romantic towers and chimneys of old sugar mills, the Great Alps Waterfall, a first class 9-hole golf course, and facilities for tennis, fishing, sailing and mountaineering.

The Montserrat National Trust constituted under the Montserrat National Trust Ordinance, 1969, has been actively engaged in the preservation of places of historic and architectural interest and of natural beauty, all of which provide added attractions for the visitor.

Value and Extent of the Tourist Industry

$\begin{array}{llr}\text { Number of tourist arrivals, } & 1968: & 7,000 \text { (est.) } \\ & 1969: & 8,000 \text { (est.) } \\ & 1970: & 12,000 \text { (est.) }\end{array}$

Foreign exchange receipts from tourism,

1968: EC $\$ 1.5$ million

1969: not available

1970: not available

Montserrat is served by B.W.I.A., B.O.A.C., PANAM, and Air Canada from New York, Miami, Toronto, Montreal and Lond on through connections with Leeward Islands Air Transport at Coolidge International Airport, Antigua. It is also linked with the other Caribbean islands by LIAT which operates two regular scheduled flights to and from Montserrat daily.

\section{Official Promotional Organisation}

The Tourist Board, which is the official tourist organisation, is a voluntary organisation. The members are appointed by the Government on the basis of their knowledge of and interest in connection with the tourist industry. The Board operates an office and information service with a fulltime paid Secretary in Plymouth. Its activities include distribution of information folders, fact sheets and brochures, participation in overseas familiarisation, publicity and promotional tours, co-operation with photographic groups, travel writers, freelance journalists and travel agents. The Board is a member of the Caribbean Travel Association and of the Association of Tourist Boards of the Eastern Caribbean an organisation which operates offices in the United Kingdom, Canada and the United States. 
The airlines, shipping lines, Taxi Drivers Association and hotels are represented on the Tourist Board. There are 5 classified hotels (28 single cottages, 15 double cottages, 38 double rooms, 20 single rooms, 5 selfcontained sufficiency units and 3 guest houses). Furnished houses and cottages with modern installations and furnishings are also available-for rental.

4. Government Participation

(i) Ownership or shares in hotels:

None.

(ii) Financial assistance specifically available (e.g. loans or guarantees):

None.

(iii) Income tax and other concessions on hotel income:

Under the Hotels Aid Ordinance, 1954, provision is made for exemption from Customs Duty on construction materials and equipment and allows for tax exemption for the first five years and for write-off of capital expenditure against profits in any 5 of the succeeding 8 years.

(iv) Import duty concessions on materials and equipment for hotel or other tourist construction:

The Development Incentives Ordinance, 1964, also encourages the establishment, conduct and expansion of any development enterprise in the Territory, by providing exemption from Customs Duty on articles imported for the construction, alteration, reconstruction or extension of the development premises or the equipment for such premises. It also grants exemption from Income Tax or Company $\mathrm{Tax}$ for a period of 7 years.

(v) Provision of public funds for publicity purposes: Government finances the Tourist Advisory Board which is responsible for promotional publicity. To boost promotional publicity in the field of tourism the sum of $\$ 30,000$ has been provided for 1971.

(vi) Government expenditure on infrastructure:

The only airstrip has recently been resurfaced, widened and lengthened to provide adequate accommodation for the Avro 748 and larger aircraft.

A revised study of a project to provide deep water berthing to facilitate cruise ships and an accompanying yacht marina to afford shelter to pleasure craft and yachts is in the advanced stages. On the 
compeltion of this study it is expected that funds will become available for the project. A Road Development Programme including access roads and the opening of new areas for the delight of tourists is in progress. An all-island water development scheme is scheduled to begin in April. Electricity supply is provided throughout the island.

5. Action Taken During the Current Year

See Section 4 (vi) above.

6. $\quad$ Future Plans for the Industry

The Government is expecting to obtain this year the services of an adviser under the British Government Technical Assistance Scheme to assist in the preparation of a comprehensive plan for the promotion of tourism and to give necessary training to the Secretary of the Tourist Board.

The immediate aim is:

(a) to expand and upgrade hotel accommodation and ancillary services;

(b) to accelerate the preservation and enhancement of places of historic and scenic interest;

(c) to introduce such other activities as may be conducive or incidental to the attraction and comfort of the holiday-maker or tourist. Reorganisation and reorientation of overseas publicity and advertisement avenues are being actively pursued.

Dialogue is going on between Government, C.D.C. and other interested agencies with a view to building a condominium. A suitable site has already been earmarked. 


\section{New Hebrides}

The tourist potential of the New Hebrides lies in the attraction of its tropical island scenery, including an easily accessible active volcano on Tanna; pleasant beaches and facilities for sailing, fishing and snorkeling; an excellent climate; its unique atmosphere as an Anglo-French Condominium; and the hospitality and friendliness of its peoples.

1. Value and Extent of Tourist Industry

Number of visitors; 1968: 3,260 (plus 5,724 cruise ship passengers)

1969: 4,745 (plus 4,026 cruise ship

1970: 6,000 (plus 610 cruise ship passengers)

Most of the visitors are from Australia, New Zealand and the United States of America. The average stay is five days.

2. Official Promotional Organisation

The Chamber of Commerce, with financial assistance from the Joint Administration, undertakes a tourist promotion programme.

3. Internal and Infrastructural Organisation

There are three hotels in Vila, the capital, on Efate Island, with a total of 280 beds. At Luganville, the administrative and commercial centre of the island of Espiritu Santo, there is a 10-room (20-bed) hotel and there are also two guest houses with a total of 32 beds. In the north of the same island, at Hog Harbour there is a 24 -room (44-bed) tourist hotel. On the island of Tanna, there are 5 twin bungalows; a total of 10 beds.

4. Government Participation

(i) Ownership or shares in hotels:

None

(ii) Financial assistance specifically available

(e.g. loans and guarantees):

None

(iii) Income tax and other concessions on hotel income:

There are no income or company or profits taxes in the New Hebrides. 
(iv) Import duty concessions on material and equipment for hotel and other tourist construction:

Duty free concessions on building materials and equipment.

(v) Provision of public funds for publicity purposes:

The Joint Administration subsidises, in full, the cost of the Chamber of Commerce's tourist publicity programme.

(vi) Government expenditure on infrastructure:

Re-surfacing of the Bauerfield aerodrome, at Vila, was completed in 1970 and there are now regular scheduled flights by medium sized jet aircraft.

Similar facilities will be available at Pekoa aerodrome, Espiritu Santo, on which work will begin in 1971. The 1971 - 75 Joint Development Plan provides for improvements to existing island airfields and the provision of additional ones which will facilitate air travel within the Group. The Development Plan also provides for a tourist industry survey and for the provision of tourist facilities on the island of Tanna where the readilyaccessible Yasur volcano is a great attraction. The new deep water wharf at Vila, which is due for completion by the end of 1971 , will be capable of accommodating cruise ships of the largest size.

\section{Action Taken During the Current Year}

The Melanesian Tourist Federation was established in 1970 with the aim of co-ordinating tourism in the four member territories: New Caledonia, New Hebrides, Territory of Papua and New Guinea, and the British Solomon Islands Protectorate. The inaugural meeting was held in Vila and two subsequent meetings were held in Honiara and Port Moresby; all of which were attended by the Secretary of the New Hebrides Chamber of Commerce who also attended the 19th Pacific Area Travel Association Conference at Auckland and the Fiji Convention on Tourism.

A small advertising programme was undertaken in the travel trade press, and the Tourist Bureau's Information Bulletins were sent to all carriers in the South Pacific and to a large number of travel agents in Australasia and North America. Information tours for some 40 Australian and American travel writers and travel agents were jointly organised by airlines and the Chamber of Commerce. The first four New Hebrides colour posters were issued and widely distributed by the Chamber of Commerce who also participated in U.T.A.'s campaign during the Captain Cook Bi-centenary and Festival of Sydney.

6. Future Plans for the Industry

See 4 (vi) above. 


\section{St. Kitts - Nevis - Anguilla}

The tourist potential of these islands in the sites of considerable historical interest, palm fringed beaches backed by mountain peaks and miles of the finest white sand beaches. Of all the Leeward and Windward Islands they are the nearest to North America and Puerto Rico, which many visitors use as their starting points for visits further south and east.

Value and Extent of the Tourist Industry

Number of tourist arrivals,

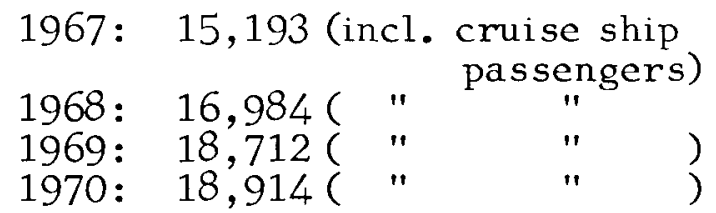

Estimated expenditure by visitors,

1967: £416,600

1968: $£ 700,000$

1969: £875,000

1970: not available

The majority of visitors arrive by air and the average length of stay is about 7 days.

The state of St. Kitts, Nevis, Anguilla is served by LIAT which connects with international airlines at Antigua and San Juan, Puerto Rico. Other airlines which serve St. Kitts are CARIBAIR which operates a daily schedule, and WINAIR which runs six flights a week, and A.L.M. with one flight weekly.

\section{Official Promotional Organisation}

There is a Tourist Board which is constituted on a representative basis. The function of the Board is primarily to advise Government on all aspects of tourism.

3. Internal and Infrastructural Organisation

Visitors usually stay at hotels which operate on the American Plan (A.P.) i.e. rates include all meals. In 1968 , there were 210 hotels rooms in the three island State with a total of 380 beds.

The Government is actively participating in tourist development prospects, especially at the Frigate Bay development on the island of St. Kitts, which is a planned tourist and residential complex. In addition, the Government is actively concerned with the construction of the new Liamuiga Hotel, which is expected to be soon operational. 
(i) Ownership or shares in hotels:

The Government is a majority shareholder in the Liamuiga Hotel and is participating in the

Frigate Bay complex.

(ii) Financial assistance specifically available (e.g. loans and guarantees):

None.

(iii) Income tax and other concessions on hotel income:

Under the Hotel Aid Ordinance, a hotel of ten rooms is able to import all building materials and articles of hotel equipment free of customs duty and pier dues, and enjoys a tax holiday for a period of five years. A hotel of thirty rooms and over gets in addition to duty free importation of building materials and equipment, a tax holiday of ten years.

(iv) Import duty concessions on materials and equipment for hotel or other tourist construction:

See (iii) above.

(v) Provision of public funds for publicity purposes: A modest allocation is provided.

(vi) Government expenditure on infrastructure:

See Section 3 above.

5. Action Taken During the Current Year.

Not available at time of publication.

6. Future Plans for the Tourist Industry

A development plan has recently been prepared which includes:

(a) extension of Golden Rock Airport to take medium range jet aircraft.

(b) development of an 850 acre estate (Frigate Bay). Golf course, hotels, housing, marina etc., are provided for.

(c) a road to the southeast peninsular which is ideal for tourist development.

(d) water improvement; and

(e) deep water harbour. 


\section{St. Lucia}

The tourist potential of St. Lucia lies in its superb beaches and fine tropical scenery.

1. Value and Extent of the Tourist Industry

$\begin{array}{lll}\text { Number of tourist arrivals, } & 1967: & 16,437 \text { (excl. intransit } \\ \text { visitors) }\end{array}$

Estimated expenditure by visitors,

1968: WI $\$ 3,812,280$ (incl. 1969: WI\$ 4,829,460 intransit 1970: WI\$ $5,549,710$ visitors)

Visitors mainly come from West Indian countries, the U.S.A., U.K. and Canada.

The majority of visitors arrive by air. British West Indian Airways and/or Leeward Islands Air Transport, based in Trinidad and Antigua respectively, call at St. Lucia daily, and link this territory with the other islands in the Caribbean. Direct connections to the United States and Canada can be made from St. Lucia over Barbados or Antigua.

Caribair, calls at St. Lucia daily, providing direct flights to and from San Juan. A.L.M., which is based in Curacao, calls at St. Lucia once per week, after which the flight returns to Curacao. Pan American and Air France, both international airlines call at Martinique, which is one short hop from St. Lucia.

\section{Official Promotional Organisation}

The St. Lucia Tourist Board is concerned with promotional development and publicity. It is an active and energetic body, and operates with a grant from Government which was $\$ 60,000$ in 1966 , and $\$ 80,000$ in 1967 and 1968.

3.

Internal and Infrastructural Organisation

The majority of visitors to St. Lucia stay in hotels where there are 520 rooms available. During 1970 approximately 200 additional rooms were added to 24 apartments. Hotel growth is indicated by the fact that the number of rooms available has grown from 286 in 1968 to 520 in 1970.

Training - To cope with the increasing demand for trained personnel to fill the growing number of vacancies in the expanding tourist industry the Government of St. Lucia has started a series of courses in the newly 
established Morne Technical College. In addition, a number of hotels are co-operating on an individual basis with the provision of training.

It has been estimated by the St. Lucia Tourist Board that by the end of 1971, approximately 1,500 additional staff in all categories will be required in the hotel industry.

4.

Government Participation

(i) Ownership or shares in hotels:

None.

(ii) Financial assistance specifically available

(e.g. loans and guarantees):

None.

(iii) Income tax and other concessions on hotel income:

The Development Incentives Ordinance provides for the granting of certain relief from income tax to companies in development enterprises, which includes the construction etc., of hotels and other tourist accommodation.

(iv) Import duty concessions on materials and equipment for hotels or other tourist construction:

Special concessions are allowed in connection with the hotels industry under the Hotel Aid Ordinance, for the importation of certain building materials and articles of hotel equipment free from customs duties.

(v) Provision of public funds for publicity purposes: $\$ 80,000$ was granted to the tourist board in 1968 . (Latest figure available)

(vi) Government expenditure in infrastructure:

None.

5. Action Taken During the Current Year

Not available at time of publication.

6. Future Plans for the Tourist Industry

Improvements have been done to the runway at Vigie Airport, and plans for the reconstruction of the terminal building are on the way. The development plan also proposed that one of the runways at Beane Field airport be lengthened to 8,000 feet, and subsequently resurfaced so as to provide overall runway length and strength for the largest jet aircraft. 


\section{St. Vincent}

The prospects for tourist development in St. Vincent and particularly in the Grenadines are excellent. The Grenadines form a unique feature of the Eastern Caribbean area, a string of small islands of great beauty, ideal for all forms of sailing, fishing and swimming with a plentiful supply of beaches and excellent climate. On the main island of St. Vincent there is a much less plentiful supply of good beaches, but no shortage of potential hotel sites in areas of great beauty.

1. Value and Extent of the Tourist Industry

$$
\begin{array}{lll}
\text { Number of tourist arrivals, } & 1968: & 12,472 \text { (excl. cruise } \\
& 1969: & 15,569(" \text { (ship passengers) } \\
& 1970: & 17,586(")
\end{array}
$$

The majority of visitors (approx.80\%) arrive by air.

In 1970 , tourism was responsible for $\$ 5.5$ million of the States' revenue and the industry now rank second only to agriculture in importance to the economy.

St. Vincent is served by British West Indian Airways from New York and Miami, and throughout the entire Caribbean by Leeward Islands Air Transport under contract with B.W.I.A. by Caribair, by B.O.A.C. from London with connections at Barbados, Antigua or Trinidad, and by Air Canada from Montreal or Toronto with similar connections.

\section{Official Promotional Organisation}

The St. Vincent Tourist Board is fully financed by the Government of St. Vincent and is an advisory body to the Minister of Tourism. The board is represented overseas by agents situated in New York, London and Toronto.

3.

Internal and Infrastmuctural Organisation

There are 21 hotels in St. Vincent and the Grenadines, and one guest house. Altogether there is a total of 449 beds. All of the hotels are small, none has more than 20 rooms. (These figures relate to 1968 ).

4.

Government Participation

(i) Ownership or shares in hotels:

None

(ii) Financial assistance specifically available

(e.g. loans or guarantees):

None 
(iii) Income tax and other concessions on hotel income:

There is a Hotel Aids Ordinance providing for a relief from Income Tax.

(iv) Import duty concessions on material and equipment for hotel or other tourist construction:

Concessions are given on material and equipment for the construction and equipment of new hotels or other tourist accommodation.

(v) Provision of public funds for publicity purposes:

Government provides funds for the small Tourist Board.

(vi) Government expenditure on infrastructure:

Government provides public services essential for hotel development such as electricity, water, telephones and roads.

5. Action Taken During the Current Year

Not available at time of publication.

6. Future Plans for the Tourist Industry (as at June, 1968)

The 1966-70 Development Plan makes provision for the reconstitution of the Tourist Board as a statutory board, for strengthening its finances and staff, and for representation abroad. The Development Plan also proposes that tourist development should concentrate on attracting the cruise ship business. A recommendation is also included in the Development Plan for expenditure of $\$ 900,000$ for a surfaced runway in Bequia, as well as $\$ 300,000$ for an airstrip on Union Island, and $\$ 300,000$ for a similar facility on Canouan Island. Recently an airstrip has been licensed on Prune Island in the Southern Grenadines. 


\section{Seychelles}

The principal tourist attractions of Seychelles are its unique scenery; magnificent beaches and bays around the main island, Mahe, and the nearby smaller islands, offering opportunities for goggling, skin-diving, sailing and other activities; tropical but healthy climate; and unspoilt character.

1. Value and Extent of the Tourist Industry

\begin{tabular}{|c|c|}
\hline Number of visitors arriving, & $\begin{array}{lr}1967: & 907 \\
1968: & 1,059 \\
1969: & 1,029 \\
1970: & 1,622\end{array}$ \\
\hline
\end{tabular}

Of the total 1,622 visitors in 1970 -

(i) $62 \%$ were on holiday; $30 \%$ were business visitors and $8 \%$ were in transits or others.

(ii) $61 \%$ were from Commonwealth countries;

(iii) their origins by continent were:- Africa: $41 \%$;

Europe: $32 \%$; America: $15 \%$; Asia: $10 \%$; Oceania: $2 \%$.

In addition to the 1,622 recorded above for 1970 there were 1,340 (mostly from U.S.A./Europe) visitors on the special cruise ship which operated to Seychelles from East Africa.

The total expenditure of the visitors in Seychelles in 1970 is estimated at roughly $£ 200,000$; this is equivalent to about $35 \%$ of total export earnings for the same year.

Because of the remoteness of Seychelles nearly all tourists arrive intending to spend their holiday in the Colony and do not go on elsewhere. The only present means of communication is by sea, approximately three sailings per month between Mombasa and Bombay, and by air, a once weekly service from Mombasa terminating in Mahe.

2. Official Promotional Organisation

There is a small Tourism Section within the Department of Tourism, Information and Broadcasting.

The Seychelles Government maintains two official representatives overseas - in Mombasa and Melbourne and has appointed a London based organisation with representation offices in Paris, Geneva and Frankfurt to be responsible for marketing and promotional activities in the U.K. and Europe. 
The average length of stay in 1970 of all visitors was 42.3 days. At present the Seychelles has 6 hotels with a total of 150 beds and one hotel on r raslin Island ( 21 miles distant) with 14 beds. A substantial proportion of visitors, particularly those staying for 2 or 3 months or more, either stay with friends or business associates or rent houses.

4. Government Participation

(i) Ownership or shares in hotels:

None, though under consideration.

(ii) Financial assistance specifically available (e.g. loans and guarantees):

The Seychelles Government, through its Tourist Loans Advisory Committee, offers small low-interest loans for small-scale tourist amenities, primarily operated by local entrepreneurs.

(iii) Income tax and other concessions on hotel income, tourism, etc. :

(a) "Investment Allowances" on construction cost of new hotels and provision of approved tourist facilities:-

$60 \%$ of expenditure allowable in first year $10 \%$ per annum $=(70 \%)$ allowable for each of next 7 years

making total of $130 \%$

(b) Company Income Tax rate is 35\% which is wholly creditable against tax of shareholder on dividends declared out of the company's taxed profits.

Personal Income Tax rates range from $4 \%$ to $35 \%$ (surtax equivalent was abolished in 1971).

(c) No hotel or tourist taxes, for example, on hotel rooms, transit (all abolished in 1970/71), departure from airport etc.

(d) Tourist goods such as cameras, films, binoculars, watches are purchasable duty-free without customs formalities.

(iv) Import duty concessions on material and equipment for hotel or other tourist facilities:

(a) All materials and equipment (but not consumables) for hotels are admitted at nil or (dependent upon country of origin) reduced rates of duty; moveables must be marked with the hotel name or crest.

(b) Similar concessions are available to restaurants and reputable bars. 
(c) Virtually all building materials are admitted on similar terms.

(v) Provision of public funds for publicity purposes:

Funds for tourism marketing have been made available under the Development Plan.

(vi) Government expenditure on infrastructure:

Development Plans include large capital sums for electricity supplies and roads and on water schemes scheduled for completion by 1981 .

\section{Action Taken During the Current Year}

The aims and objectives of the Government's White Paper on Tourism Development in the Seychelles are being implemented in accordance with the approved development Master Plan.

6. Future Plans for the Industry

In accordance with the White Paper on Tourism Development, hotel and amenities construction is broadly following the assessed growth and during 1970 work commenced on two hotels, one of 100 beds and the other of 300 beds both opening in 1971 with two more of 300 beds each in the early planning stage for anticipated completion in 1972.

Work on the airport is progressing and the planned operational date of July, 1971 is to be achieved.

Work continues on the Town Centre and Port Area, reclamation having finished; infrastructure and services are now being installed in preparation for building work commencing in 1972. 


\section{Turks and Caicos Islands}

The tourist potential of these islands depends on the excellent climate, superb beaches, crystal clear sea and abundance of fish. Facilities for diving are exceptional due to the clarity of the sea and the extent of reefs and ancient wrecks. All the major islands have good airstrips, two of which have refuelling facilities and South Caicos has a good natural harbour for yachts. The islands abound in unspoilt natural beauty.

1. Value and Extent of the Tourist Industry

The tourist industry is in its infancy but there are now small hotels on Providenciales, South Caicos and Grand Turk and new hotels are due to be started soon on North and Middle Caicos. There are signs that tourism will become a major industry within the next five years. Already sma!l numbers of tourists are visiting the islands from the United States, Canada, England and Scandinavia. They come mostly by air either by scheduled Air Caicos flights or by private plane and a few by yacht. Two internal airlines provide frequent services between the islands.

2. Official Promotional Organisation

A Tourist Board has recently been appointed which will answer enquiries and issue a publicity brochure in the near future.

3. Internal and Infrastructural Organisation

There are now three hotels operating in the islands with accommodation for 82 visitors. Grand Turk and South Caicos have paved airfields of 5,500 and 6,500 feet respectively with Customs and Immigration facilities on Providenciales and 3,000 feet gravel strips on North Caicos and Middle Caicos.

4. Government Participation

(i) Ownership or share in hotels:

None

(ii) Financial assistance specifically available:

None

(iii) Income tax and other concessions on hotel income:

There is no income tax in the Islands.

(iv) Import duty concessions on materials and equipment

for hotel and other tourist construction:

Under a Hotels Aid Law, materials and many items of 
equipment are exempt from duty. Plant and machinery for hotel construction are also exempt from duty.

(v) Provision of public funds for publicity purposes: None until the industry develops more.

(vi) Government expenditure on infrastructure:

The territory is grant-aided by the British Government and has very limited resources. Capital development is being undertaken in the form of roads and airfields on islands where no private development projects are yet established. Wherever possible infrastructure is provided by private developers in payment for Crown land.

\section{Action Taken During the Current Year}

Negotiations with development companies were suspended on the instructions of H.M. Government pending the appointment of planning consultants to prepare an overall development plan. The consultants will produce their report by mid-1971.

\section{Future Plans for the Industry}

Messrs. Shankland Cox and Associates are preparing an overall development plan for the islands which is expected to be completed by mid1971. Thereafter it is hoped that action will be taken quickly to implement the plan and open the islands for tourist investment. 
Chairman:

Mr. T.E. Gooneratne (Deputy Secretary-General)

Commonwealth Secretariat

\title{
Members ${ }^{*}$
}

Mr. E.R.J. Hall,

Australian High Commission

Miss Denise Hope

Barbados Tourist Board

Mr.W.R. Reece,

British Travel Association

Mr. G.W. Powell,

Canadian Government Travel Bureau
Mr.S.R. Ratnakar, Indian Tourist Office

Mr. K. Meadows, Kenya Tourist Office

Mr. N. Ibraham, Malaysian High Commission

Mr. Ihebom Egedo, Nigerian High Commission

\author{
Secretariat \\ Mr. N.C.Sen Gupta \\ Mr. D.R. Clarke \\ Mr. R. Galletti \\ Mr. M. Mbayah \\ Miss S. Hyne
}

* Members of the Working Party did not act as Government representatives, but in a personal capacity. 